https://nv.nltu.edu.ua

https://doi.org/10.36930/40300204

\title{
ВПЛИВ ГЕРБІЦИДІВ НА ЗАБУР' ЯНЕНІСТЬ КУЛЬТУР СОСНИ ЗВИЧАЙНОЇ (PINUS SYLVESTRIS L.) В УМОВАХ КИЇВСЬКОГО ПОЛІССЯ
}

\begin{abstract}
Наведено результати досліджень щодо випробовування гербіцидів під час здійснення хімічних доглядів за лісовими культурами. Для дослідів використано гербіциди Річард, Пікадор, Гліфовіт і Булон у комбінації з прилипачем Олемікс і без нього. На дослідній ділянці трав'яна рослинність була представлена типовими для Київського Полісся видами: куничник наземний (Calamagrostis epigejos (L.) Roth.), злинка канадська (Erigeron canadensis L.), щавель горобиний (Rumex acetosella L.), тонконіг звичайний (Poa trivialis L.), напівчагарник ожина (Eubatus). Найбільш забур'яненими були міжряддя. Тут переважав куничник наземний, а однорічні бур'яни, переважно злинка канадська, траплялися поодиноко. На схилі i дні борозен також переважав куничник та у незначній кількості росли однорічні види. На дні борозен і на їх схилах кількість бур'янів була практично однаковою. Досліди закладено на лісових культурах 2018 року. Культури створено у лісовому фонді ДП "Київська лісова науково-дослідна станція" на суцільному зрубі, по борознах, в умовах свіжого субору. Доповнення культур здійснювали навесні 2019 року. Для обробляння рослин використовували ручні оприскувачі. Під час хімічного догляду за лісовими культурами сосни звичайної (Pinus sylvestris L.) гербіцидна дія препаратів полягала у пригніченні росту небажаної трав'яної рослинності та в частковому її знищенні. Застосування гербіцидних препаратів Річард, Гліфовіт і Булон призвело до знищення від 52 до 68 \% багаторічних бур'янів. Найменше багаторічників було знищено гербіцидом Пікадор, тільки 37 \%. Причому такий результат було досягнуто як застосуванням препарату Пікадор у комбінації з прилипачем Олемікс, так і без нього. Водночас, Пікадор повністю знищив однорічні бур'яни. Стосовно дії гербіцидів у комбінації з прилипачем встановлено, що його застосування істотно не впливало на ефективність гербіцидів. Усі гербіциди спричинили відпад сосни. Найбільше пошкоджень (21 \%) виявлено під час застосування гербіциду Річард. Встановлено, що хімічний догляд негативно вплинув на однорічні рослини сосни звичайної, якими було доповнено лісові культури.

Ключові слова: гербіцидна дія; хімічний догляд; Річард; Пікадор; Гліфовіт; Булон; доповнення культур; багаторічні бур'яни.
\end{abstract}

Вступ. Процеси створення і вирощування лісових культур сосни звичайної є високозатратними. Велика частка витрат припадає на боротьбу з небажаною рослинністю, оскільки найбільшу небезпеку для сосни становить конкуренція із трав'яною рослинністю і листяними породами дерев у перші роки росту культур [5]. Часто незадовільний стан соснових культур, інколи їхня загибель, зокрема в Київському Поліссі, зумовлені недостатніми кількістю та якістю доглядів. Хімічний метод зниження конкуренції з боку небажаної рослинності шляхом застосування сучасних гербіцидів, які відповідають вимогам сучасної екологічної безпеки, є найбільш ефективним і економічним [2]. Застосування гербіцидів на ділянках, де запроектовано проведення доглядів, сприяє підвищенню збережуваності лісових культур сосни звичайної [8]. Обробіток грунту гербіцидами, як інгібіторами процесу росту і розвитку небажаної трав'яної рослинності, допомагає скоротити або взагалі видалити зі складу живого надгрунтового покриву участь трав'яних видів.
Хімічні догляди за лісовими культурами сосни звичайної $є$ ефективним засобом обмеження розвитку небажаної рослинності $[7,11]$. 3i 40-х років XX ст. у різних країнах світу під час хімічного обробляння грунту випробували хлорати, роданисті солі, сульфат амонію, трихлорацетат натрію, далапон, амінотриазол та інші гербіциди [3]. Високу ефективність показали Раундап, РК (розчинний концентрат) (360 г/л гліфосату), Анкор85 ВДГ (водно-дисперсні гранули) (750 г/кг калійної солі сульфометурн-метилу) та Арсенал, РК (250 г/л імазапіру) [6]. В Україні, під час проведення хімічних доглядів за лісовими культурами, створеними на суцільних зрубах, застосовують переважно препарати на підставі гліфосату [1].

До "Переліку пестицидів і агрохімікатів, дозволених для використання в Україні", включено 597 препаратів, які належать до групи "гербіциди", при цьому в основі 71 препарату діючою речовиною $є$ гліфосат, в основі 4 препаратів - імазетапір. Серед такої кількості гербіцидів складно визначити найефективніші препарати для

\section{Інформація про авторів:}

Хромуляк Олександр Ігорович, т.в.о. директора. Email: chsascha@gmail.com

Савущик Микола Петрович, канд. С.-г. наук, заступник директора з наукової роботи. Email: savushik@ukr.net

Шлончак Григорій Андрійович, канд. с.-г. наук, ст. науковий співробітник. Email: klnds@ukr.net

Цитування за ДСтУ: Хромуляк О. І., Савущик М. П., Шлончак Г. А. Вплив гербіцидів на забур'яненість культур сосни звичайної (Pinus sylvestris L.) в умовах Київського Полісся. Науковий вісник НлТУ України. 2020, т. 30, № 2. С. $24-27$.

Citation APA: Khromulyak, A. I., Savushchik, M. P., Shlonchak, G. A. (2020). Effect of herbicides on the pollution of pine cultures (Pinus sylvestris L.) in conditions of the Kyiv Polish. Scientific Bulletin of UNFU, 30(2), 24-27. https://doi.org/10.36930/40300204 
боротьби з небажаною трав'яною рослинністю в лісових культурах, які забезпечують весь спектр необхідної дії, зокрема, загибель максимальної кількості видів шляхом одноразового обробітку, високу збережуваність сосни, а також можливість обробітку впродовж усього періоду іiі росту. Для цього потрібно виконувати комплекс експериментальних робіт у польових умовах. Сaме результати досліджень впливу сучасних гербіцидів на ріст бур'янів у лісових культурах викладено у цій науковій роботі. Вони мають практичне значення для планування хімічного догляду за культурами сосни в умовах Київського Полісся.

Об'єкт дослідження - процеси забур'яненості і стан культур сосни звичайної під час проведення хімічного догляду в умовах Київського Полісся.

Предмет дослідження - методи і засоби, які дають змогу визначити особливості розвитку бур'янів і збереження сосни під час застосування гербіцидів у лісових культурах Київського Полісся.

Мета дослідження - виявити ефективні гербіциди і способи їх застосування для боротьби з небажаною трав'яною рослинністю під час проведення хімічних доглядів у лісових культурах сосни звичайної.

Для досягнення зазначеної мети потрібно виконати такі основні завданняи дослідження:

- з'ясувати, як випробовувані гербіциди впливають на знищення бур'янів у культурах сосни звичайної;

- встановити, як використання прилипача Олемікс впливає на ефективність гербіцидної дії препаратів на небажану рослинність;

- вияснити, як випробовувані гербіциди спричиняють відпад сосни, якою доповнюють культури;

- дослідити, які гербіциди найефективніше впливають на показники знищення небажаної рослинності та збереженості сосни.

Наукова новизна результатів дослідження полягає у тому, що було вперше встановлено, що випробовувані гербіциди спричиняють незначний відпад сосни, переважно тієї, якою доповнюють культури, насамперед у разі застосування гербіциду Річард.

Практична значущість результатів дослідження полягає у тому, що випробовувані гербіциди не призводять до повного знищення бур'янів у культурах сосни звичайної. Водночас використання прилипача Олемікс достовірно не впливає на ефективність гербіцидної дії препаратів на небажану рослинність.

Матеріал і методи дослідження. Як вже було зазначено вище, об'єктом дослідження є ділянка лісових культур сосни звичайної 2018 р. створення в умовах свіжого субору у кв. 109 виділ 4 Старопетрівського лісництва ДП "Київська лісова науково-дослідна станція" (зруб після суцільної санітарної рубки, культури створено чистими, садіння рослин здійснювали у дно борозен). Доповнення культур виконували навесні 2019 р.

Перед застосуванням гербіцидів закладено облікові ділянки площею $1 \mathrm{~m}^{2}$, на яких ретельно підраховували всю небажану рослинність за іiі кількістю і видовим складом.

Обробіток ділянки гербіцидами було проведено у другій половині вегетаційного періоду 2019 р. Для обприскування грунту і рослин використовували ручні оприскувачі. На час внесення гербіцидів сосна звичайна закінчила ріст по висоті, відбулося закладання верхівкової бруньки й одерев'яніння пагонів поточного року.
Як інгібітори росту і розвитку небажаної рослинності було використано препарати, які входять до "Переліку пестицидів і агрохімікатів, дозволених для використання в Україні": Річард, Булон, Гліфовіт (на підставі гліфосату, універсальний гербіцид) і Пікадор (на підставі імазетапіру, універсальний гербіцид). Гербіциди вносили 3 використанням прилипача Олемікс, який призначений для покращення ефективності дії препаратів. Дослід було закладено в триразовій повторюваності. Гербіциди Річард, Пікадор і Гліфовіт застосовували як самостійно, так і в суміші із прилипачем Олемікс. Гербіцид Булон містить прилипач, тому його додатково під час застосування не використовували. Усі препарати належать до III класу небезпечності - помірно небезпечні [4]. Усього запропоновано сім варіантів їхнього застосування і контролю:

- Річард РК (гліфосат у формі ізопропіламінної солі, 480 г/л), норма витрати - 2,0 л/га;

- Річард, 2,0 л/га + Олемікс, 1,0 л/га;

- Булон, РК (Гліфосату калійна сіль, 613 г/л у кислотному еквіваленті 500 г/л), 2,0 л/га;

- Пікадор, РК (імазетапір, 100 г/л), 1,0 л/га;

- Пікадор 1,0 л/га +Олемікс, 1,0 л/га;

- Гліфовіт, РК (ізопропіламінна сіль гліфосату 360 г/л), $2,5 \pi /$ га;

- Гліфовіт 2,5 л/га +Олемікс, 1,0 л/га.

Усі досліди з гербіцидами й обліки стану трав'яної і деревної рослинності, які здійснювали під час проведення досліджень, виконували відповідно до методичних рекомендацій, наведених у роботі [10]. На всіх дослідних і контрольних ділянках проводили обліки стану живого надгрунтового покриву, а також збережуваності культур сосни звичайної.

Під час визначення стану трав'яної рослинності використовували метод облікових ділянок. На кожній дослідній і контрольній ділянках закладали по 10 ділянок розміром $1,0 \times 1,0$ м. Для оцінювання впливу гербіцидів на небажану трав'яну рослинність використовували такі показники, як проективне покриття бур'янами облікових ділянок і кількість рослин на $1 \mathrm{~m}^{2}$. Отримані дані обробляли методами математичної статистики [9] за допомогою пакету програм MS Excel.

Результати дослідження та їх обговорення. До проведення доглядів на ділянках було досліджено заростання бур'янами різних елементів мікрорельєфу, який утворюється під час підготовки грунту для створення лісових культур шляхом улаштування плужних борозен. Встановлено, що активне заростання зрубів трав'яною рослинністю відбулося одразу після рубки і культури сосни звичайної потерпали від конкуренції з боку небажаної рослинності (табл. 1).

Табл. 1. Забур'яненість різних елементів мікрорельєфу на ділянці лісових культур

\begin{tabular}{|c|c|c|c|c|}
\hline \multirow{2}{*}{$\begin{array}{c}\text { Елемент мік- } \\
\text { рорельєфу }\end{array}$} & \multicolumn{3}{|c|}{$\begin{array}{c}\text { Середня кількість бур'янів, } \\
\text { шт. } / \mathrm{M}^{2}\end{array}$} & \multirow{2}{*}{\begin{tabular}{|c|} 
Повітряно- \\
суха маса \\
бур'янів, г/м² \\
\end{tabular}} \\
\hline & багаторічних & однорічних & всього & \\
\hline Дно борозни & 25 & 2 & 27 & 96,0 \\
\hline Схил борозни & 28 & 2 & 30 & 95,6 \\
\hline Міжряддя & 37 & 3 & 40 & 111,3 \\
\hline
\end{tabular}

Трав'яна рослинність була представлена типовими видами для Київського Полісся. Найбільше поширення мали: куничник наземний (Calamagrostis epigejos (L.) Roth.), злинка канадська (Erigeron canadensis L.), ща- 
вель горобиний (Rumex acetosella L.), тонконіг звичайний (Poa trivialis L.), напівчагарник ожина (Eubatus).

На червень, період, коли особливо активно відбувається ріст рослинності, найбільше забур'яненими були міжряддя. Тут переважав куничник наземний (Calamagrostis epigejos), а однорічні бур'яни, переважно злинка канадська (Erigeron canadensis), траплялися поодиноко. На схилі і дні борозен також переважав куничник наземний (Calamagrostis epigejos) та у незначній кількості росли однорічні види. Варто зазначити, що на дні борозен і на їх схилах кількість бур'янів була практично однаковою.

Ефективність знищення бур'янів гербіцидами через місяць після їх внесення наведено в табл. 2.

Табл. 2. Ефективність дії гербіцидів під час проведення хімічного догляду за лісовими культурами

\begin{tabular}{|c|c|c|c|c|c|c|}
\hline \multirow{4}{*}{ Гербіцид } & \multicolumn{6}{|c|}{ Середня кількість бур'янів } \\
\hline & \multicolumn{3}{|c|}{ багаторічних } & \multicolumn{3}{|c|}{ однорічних } \\
\hline & \multirow{2}{*}{$\begin{array}{c}\text { до об- } \\
\text { робітку, } \\
\text { шт./м² }\end{array}$} & \multicolumn{2}{|c|}{$\begin{array}{c}\text { після обро- } \\
\text { бітку }\end{array}$} & \multirow{2}{*}{$\begin{array}{c}\text { до об- } \\
\text { робітку, } \\
\text { шт./м² }\end{array}$} & \multicolumn{2}{|c|}{$\begin{array}{c}\text { після обро } \\
\text { бітку }\end{array}$} \\
\hline & & шт./M $/ \mathrm{M}^{2}$ & $\%$ & & шт./M² & $\%$ \\
\hline Річард & 101 & 36 & 36 & 0 & 0 & 0 \\
\hline Річард+Олемікс & 37 & 12 & 32 & 0 & 0 & 0 \\
\hline Булон & 62 & 30 & 48 & 6 & 0 & 0 \\
\hline Пікадор & 41 & 26 & 63 & 5 & 0 & 0 \\
\hline Пікадор+Олемікс & 49 & 30 & 61 & 2 & 0 & 0 \\
\hline Гліфовіт & 54 & 17 & 32 & 17 & 4 & 23 \\
\hline Гліфовіт+Олемікс & 58 & 23 & 40 & 0 & 0 & 0 \\
\hline
\end{tabular}

Наведені дані показують, що гербіцидна дія препаратів на багаторічні бур'яни мала схожий ефект, не призводячи до їх повного знищення, залишаючи після обробітку 32-63 \%. Найменше багаторічників було знищено гербіцидом Пікадор - 37 \%. Причому такий результат було досягнуто як застосуванням препарату у комбінації із прилипачем, так і без нього. Проте Пікадор на дослідних ділянках повністю знищив однорічні бур'яни. На ділянці, обробленій Гліфовітом, залишилось рости $23 \%$ однорічників.

Дуже важливою характеристикою успішності хімічного догляду за лісовими культурами є ступінь їх пошкодження гербіцидами (рисунок). Наведені дані свідчать, що застосовувані гербіциди спричинили незначний відпад сосни. Найбільше пошкоджень (21\%) виявилось у разі застосування гербіциду Річард. При цьому варто зазначити, що хімічний догляд виконували у дворічних культурах, які навесні наступного року було доповнено однорічними сіянцями.

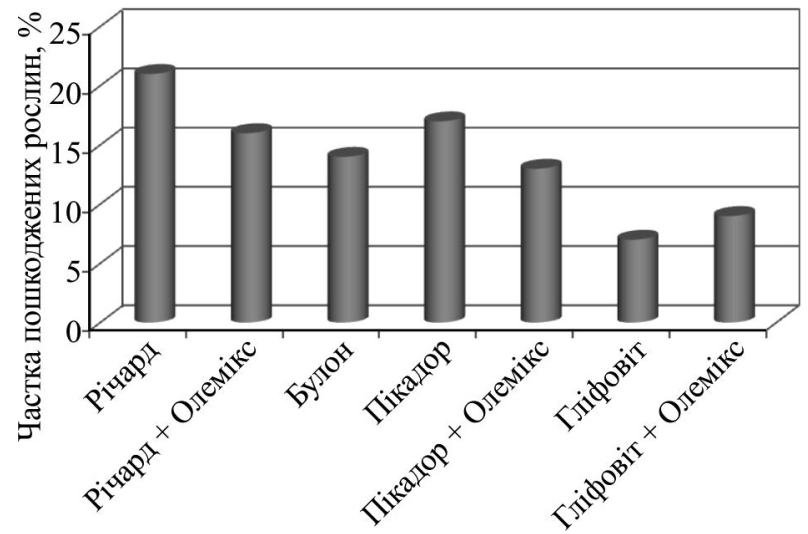

Рисунок. Пошкоджуваність культур сосни звичайної різними гербіцидами
Обліки пошкоджуваності культур показали, що наведені величини відпаду припадають саме на однорічні рослини сосни звичайної, які використовували для доповнення. Однофакторним дисперсійним аналізом не установлено ефективності впливу прилипача Олемікс на гербіцидну дію препаратів на небажану рослинність $(F \phi=0,005>F m(0,95)=7,71)$. Відповідні дані отримано щодо впливу Олеміксу на частку пошкоджених рослин сосни звичайної $(F \phi=0,25>F m(0,95)=7,71)$.

Шляхом ранжування показників частки пошкоджених рослин сосни звичайної і частки знищених бур'янів установлено, що найефективнішими препаратами як для знищення небажаної рослинності, так і для збереженості сосни виявилися Булон і Пікадор. Незважаючи на те, що найвищу збережуваність сосни виявлено під час застосування Гліфовіту, при цьому загибель небажаної рослинності $є$ низькою, особливо однорічних бур'янів. Неефективним у частині негативного впливу на збережуваність сосни виявився Річард.

Висновки. Внаслідок проведення досліджень було виявлено ефективні гербіциди і способи їх застосування для боротьби з небажаною трав'яною рослинністю під час проведення хімічних доглядів у лісових культурах сосни звичайної. За результатами дослідження можна зробити такі основні висновки:

1. Випробовувані гербіциди не призводять до повного знищення бур'янів у культурах сосни звичайної. Застосування препаратів Річард, Гліфовіт і Булон знищує від 52 до $68 \%$ багаторічних бур'янів.

2. Використання прилипача Олемікс достовірно не впливає на ефективність гербіцидної дії препаратів на небажану рослинність.

3. Випробовувані гербіциди спричиняють незначний відпад сосни, переважно тієї, якою доповнюють культури. Найбільше пошкоджень (21 \%) виявилось у разі застосування гербіциду Річард.

4. Зважаючи на показники знищення небажаної рослинності і збереженості сосни, найефективнішими виявились гербіциди Булон і Пікадор.

\section{References}

1. Boltenkov, Yu. O., Stovbunenko, D. V., \& Ustskyi, I. M. (2010). Rekomendatsii z vykorystannia herbitsydnykh preparativ dlia provedennia khimichnykh propolok $\mathrm{v}$ kulturakh sosny zvychainoi $\mathrm{v}$ umovakh Lisostepu ta Polissia Ukrainy. Kharkiv: UkrNDILHA, 10 p. [In Ukrainian].

2. Brodovych, R. I., Havrusevych, A. M., Porada, T. M. ta in. (1990). Praktychni rekomendatsii po zastosuvanniu herbitsydiv i arborytsydiv v lisovomu hospodarstvi Karpat. Ivano-Frankivsk: Oblpolihrafvydav, 35 p. [In Ukrainian].

3. Dekatov, N. E. (1966). Primenenie gerbitcidov i arboritcidov v lesnom khoziaistve. Moscow: Lesnaia prom.-st, 169 p. [In Russian].

4. DSP 8.8.1.2.002-98. (1998). Derzhavni sanitarni pravyla i hihiienichni normy "Hihiienichna klasyfikatsiia pestytsydiv za stupenem nebezpechnosti". [In Ukrainian].

5. Egorov, A. B., Postnikov, A. M., Bubnov, A. A., Pavliuchenkova, L. N., \& Partolina, A. N. (2017). Primenenie gerbitcidov pri obrabotke ploshhadei pod kultury sosny i eli, sozdavaemye seiantcami s zakrytoi kornevoi sistemoi. Trudy Sankt-Peterburgskogo nauchno-issledovatelskogo instituta lesnogo khaziaistva, 3, 47-60. [In Russian].

6. Egorov, A., Postnikov, A., Bubnov, A. et al. (2019). The use of herbicides in cultivation of spruce and pine in the Northwest Russia IOP Conf. Ser.: Earth Environ. Sci. 316. https://doi.org/10.1088/1755-1315/316/1/012078 
7. Harrington, T., Rader-Dixon, L., \& Taylor, J. (2003). Kudzu (Pueraria montana) community responses to herbicides, burning, and high-density loblolly pine. Weed Science, 51(6). https://doi.org/10.1614/02-142

8. Hordiienko, M. I., Huz, M. M., Debryniuk, Yu. M., Maurer, V. M. (2005). Lisovi kultury. Lviv: Kamula, 608 p. [In Ukrainian].

9. Lapach, S. N., Chubenko, A. V., \& Babich, P. N. (2001). Statisticheskie metody $\mathrm{v}$ mediko-biologicheskikh issledovaniiakh $\mathrm{s}$ ispolzovaniem Excel. Kiev: Morion, 408 p. [In Russian].
10. Metodika. (1990). Metodika ispytanii gerbitcidov i arboritcidov v lesnom khoziaistve. Leningrad: LenNIILKh, 44 p. [In Russian].

11. Zutter, B. R., Glover, G. R., \& Gjerstad, D. H. (1986). Effects of Herbaceous Weed Control Using Herbicides on a Young Loblolly Pine Plantation. Forest Science, 32. https://doi.org/10.1093/forestscience/32.4.882

A. I. Khromulyak, M. P. Savushchik, G. A. Shlonchak

State Enterprise "Kiev Forest Research Station", Lyutizh, Ukraine

\section{EFFECT OF HERBICIDES ON THE POLLUTION OF PINE CULTURES (PINUS SYLVESTRIS L.) IN CONDITIONS OF THE KYIV POLISH}

The results of studies of the application of modern herbicides in chemical care of forest crops of pine (Pinus sylvestris L.) are presented. The experiments were performed using the method of accounting plates. Each variant is laid out in $3 \mathrm{x}$ repetitive. Researches were conducted in Kyiv Polissya on forest crops of 2018 creation. The crops were created in the forest fund of the SE "Kyiv Forest Research Station" on a solid log, in the furrows, in the conditions of a fresh sump. Cultures were supplemented in spring 2019. Hand sprayers were used to treat the plants. At the time of application of herbicides, pine plants have completed height growth. The herbicides Richard, Boulogne, Glyphovit, Picador and the Olemix stick were used. All drugs belong to class III - moderately dangerous. Studies have shown that herbaceous vegetation was represented by species typical for the Kiev Polesie. The most common were Calamagrostis epigejos (L.) Roth., Erigeron canadensis L., Rumex acetosella L., Poa trivialis L., Eubatus. The herbicidal action of the drugs on perennial weeds did not lead to their complete destruction. The use of herbicide drugs Richard, Glyfovit and Boulogne resulted in the destruction of 52 to $68 \%$ of perennial weeds. The lowest number of perennials was destroyed by Picador herbicide $37 \%$. This result was achieved both by using the drug in combination with and without the adhesive. Picador at the test sites completely destroyed the annual weeds. In the area treated with Glyphovite, $23 \%$ of annuals remain to grow. The use of Olemix adhesive did not significantly affect the herbicidal effect of the drugs. The applied herbicides caused a slight fall in the pine. The largest amount of damage $(21 \%)$ occurred with the application of the Richard herbicide. Chemical care was carried out in two-year crops, which were supplemented with annual seedlings. Accounts of the damage to crops showed that the annual plants of pine, which they used to supplement, had fallen away. The fall of the annual pine was caused by all the herbicides tested.

Keywords: herbicide action; chemical care; Richard; Picador; Glyphovite; Boulogne; crop supplement; perennial weeds. 